\title{
The determination of the true digestibilities of interesterified fats in young pigs
}

\author{
By C. P. FREEMAN, D. W. HOLME AND E. F. ANNISON \\ Unilever Research Laboratory, Colworth House, Sharnbrook, Bedford
}

(Received I9 fanuary 1968-Accepted 9 May 1968)

\begin{abstract}
I. The true digestibilities of esterified lauric, palmitic, stearic and oleic acids in lard, coconut oil and soya-bean oil were determined by incorporating the $\left[\mathrm{I}-{ }^{14} \mathrm{C}\right]$-labelled acids into the fats by interestification. The true digestibilities of the labelled fats also were compared with the digestibilities of their unlabelled counterparts, corrected for endogenous fat by the conventional procedure.

2. The true and corrected coefficients of digestibility of each of the fats were in good agreement, but there were significant differences between the true and corrected coefficients for individual fatty acids, particularly for palmitic and stearic acids.

3. The amount of endogenous fat produced with each of the fats calculated from the values found with the labelled fatty acids was greatest when the fat supplement was lard, when a disproportionately high level of palmitic acid was excreted.

4. Evidence was obtained of the extensive hydrogenation of oleic acid in the digestive tract of the pig.
\end{abstract}

Interpretation of the digestibilities of fats, obtained in conventional digestibility experiments, is made difficult by the contribution of endogenous fat to faecal fat excretion. In practice, corrections, based on the output of fat when a fat-free or low-fat diet is given, are usually applied to the apparent digestibility values. These corrections are based on the assumption that the production of endogenous fat is not changed by the level or composition of dietary fat. In an assessment of pig faecal fat not of immediate dietary origin, Bayley \& Lewis $(1965)$ found little change in faecal fat output when the fat content of their cereal-based diet was reduced from $2.6 \%$ to $0.6 \%$. On this basis they made the assumption that endogenous fat production remained constant, providing that the same type of ration is used under the same conditions, irrespective of level of fat intake. There is, however, no direct evidence to prove that, when fats of different composition are included in high-fat diets containing up to $15 \%$ fat, the amount and composition of endogenous faecal fat remains unchanged. We have examined the validity of the assumption made by Bayley \& Lewis (1965) by comparing the true digestibilities of $\left[{ }^{1-14} \mathrm{C}\right]$-labelled fats with the corrected digestibilities, determined by the conventional procedure, of the unlabelled counterparts of these fats.

Three fats-lard, soya-bean oil and coconut oil-chosen for their widely differing fatty acid composition, were examined. The labelling was achieved by incorporating $\left[\mathrm{I}-{ }^{14} \mathrm{C}\right]$-labelled palmitic, stearic and oleic acids, and in the diets with coconut oil also $\left[\mathrm{I}^{14} \mathrm{C}\right]$ lauric acid, into the triglycerides by interesterification. The digestibilities of the natural fats were also examined. 


\section{EXPERIMENTAL}

Animals and experimental design. The experiment was designed in randomized incomplete block form, each block consisting of four litter-mate pigs. A total of twentyeight pigs was used in seven such blocks. The pigs were Large Whites (except two litters which were Large White $\times$ Wessex crosses) which had been weaned at 8 weeks and weighed $16-18 \mathrm{~kg}$ at the beginning of the experiment. There were seven experimental treatments, namely control (basal diet, no added fat), 10\% natural soya-bean oil, 10\% interesterified soya-bean oil, 10\% natural lard, 10\% interesterified lard, 10\% natural coconut oil, and $10 \%$ interesterified coconut oil.

\section{Table $\mathrm{I}$. Composition and proximate analysis of basal and fat-supplemented diets}

\begin{tabular}{lcc} 
& \multicolumn{2}{c}{ Composition (\%) } \\
\cline { 2 - 3 } \multicolumn{1}{c}{ Ingredient } & Basal diet & diet \\
Extracted soya-bean meal & 17.5 & 17.5 \\
Wheat & 15.0 & 15.0 \\
Barley & 53.5 & 53.5 \\
Dicalcium phosphate & 3.5 & 3.5 \\
Salt & 0.5 & 0.5 \\
Maize starch & 10.0 & - \\
Soya-bean oil, lard or coconut oil & - & 10.0 \\
Vitamins and minerals & $*$ & $*$
\end{tabular}

* Mineral premix to supply (g/ton): zinc oxide 134 , ferrous sulphate 1000 , manganese sulphate Ioo; copper sulphate 505 ; vitamin premix to supply (per ton): retinol 3900000 i.u., cholecalciferol 835000 i.u., riboflavine $2 \cdot 25 \mathrm{~g}$, cyanocobalamin $20 \mathrm{~g}$.

\begin{tabular}{ccccccc}
\multicolumn{7}{c}{ Proximate analysis of basal diet (\% of dry matter) } \\
Moisture & $\begin{array}{c}\text { Ether } \\
\text { extract }\end{array}$ & $\begin{array}{c}\text { Crude } \\
\text { protein }\end{array}$ & $\begin{array}{c}\text { Crude } \\
\text { fibre }\end{array}$ & Ash & Calcium & Phosphorus \\
13.3 & 1.7 & 16.5 & 4.2 & 5.7 & 1.0 & 0.9
\end{tabular}

Preparation of the interesterified and labelled fats. The large-scale preparation of interesterified triglycerides was carried out by Price's (Bromborough) Ltd, Cheshire. The labelled triglycerides were prepared by interesterification on the laboratory scale. $\left[{ }^{14}-{ }^{14} \mathrm{C}\right]$-labelled palmitic, stearic and oleic acids, after conversion into their methyl esters, were incorporated into lard or soya-bean oil by interesterification in hexane for $6 \mathrm{~h}$, under nitrogen, using a sodium methoxide catalyst ( $1 \%$ ). Under these conditions, complete randomization of the constituent triglycerides is achieved (Täufel, Franzke \& Achtzehn, 1958). The product was washed with dilute acetic acid, then with $5 \%$ sodium bicarbonate solution, and finally with water. After drying over sodium sulphate, the solvent was removed by rotary evaporation under reduced pressure. Labelled interesterified coconut oil was prepared under the same conditions, using $\left[\mathrm{I}^{-14} \mathrm{C}\right]$-labelled lauric, palmitic, stearic and oleic acids. The level of activity introduced into each fat was such that the specific radioactivity of each fatty acid in the final product was approximately $20 \mu \mathrm{c} / \mathrm{g}$. 
Diets. The compositions of the basal diet and of the fat-supplemented diets are given in Table I. In the fat-supplemented diets, 10\% maize starch of the basal diet was replaced by $10 \%$ of the appropriate labelled or unlabelled fat (Table I). The labelled fat was mixed with about five parts of unlabelled fat before incorporation into the diet. The fatty acid composition of the diets is given in Table 2. The values illustrate the very different composition of the three fats used in the experiment, ranging from the highly unsaturated soya-bean oil to coconut oil, which, though predominantly saturated, is rich in medium-chain fatty acids, in particular lauric acid. Comparison of the fatty acid composition of each natural fat and its interesterified form showed that interesterification was achieved without loss of any specific fatty acid.

Table 2. Major fatty acid compositions (weight percentages of the total) of the basal and fat-supplemented diets

\begin{tabular}{|c|c|c|c|c|c|c|c|}
\hline $\begin{array}{c}\text { Fatty } \\
\text { acid }\end{array}$ & $\begin{array}{c}\text { Basal } \\
\text { diet }\end{array}$ & $\begin{array}{c}\text { Basal } \\
\text { diet }+ \\
\text { natural } \\
\text { soya-bean oil }\end{array}$ & $\begin{array}{c}\text { Basal } \\
\text { diet }+ \\
\text { inter- } \\
\text { esterified } \\
\text { soya-bean oil }\end{array}$ & $\begin{array}{c}\text { Basal } \\
\text { diet }+ \\
\text { natural lard }\end{array}$ & $\begin{array}{c}\text { Basal } \\
\text { diet }+ \\
\text { inter- } \\
\text { esterified } \\
\text { lard }\end{array}$ & $\begin{array}{c}\text { Basal } \\
\text { diet } t \\
\text { natural } \\
\text { coconut oil }\end{array}$ & $\begin{array}{c}\text { Basal } \\
\text { diet }+ \\
\text { inter- } \\
\text { esterified } \\
\text { coconut oil }\end{array}$ \\
\hline I0:0 & - & 一 & - & 一 & 一 & $5^{\circ} \mathrm{I}$ & $4 \cdot 0$ \\
\hline $12: 0$ & - & - & - & - & - & $33 \cdot 8$ & $32 \cdot 2$ \\
\hline $14: 0$ & - & - & - & $I \cdot 7$ & $2 \cdot 0$ & 16.7 & $16 \cdot 5$ \\
\hline $16: 0$ & $21 \cdot 2$ & II $\cdot 9$ & $12 \cdot 3$ & $23 \cdot 7$ & $24 \cdot 2$ & I4:I & 14.0 \\
\hline $18: 0$ & $2 \cdot 2$ & $3 \cdot 8$ & $3 \cdot 9$ & $x 1.8$ & II & $4^{6} 6$ & $5 \cdot 2$ \\
\hline I8: I & $16 \cdot I$ & $24 \cdot 7$ & 23.7 & $42 \cdot 5$ & $4 \mathrm{I} \cdot \mathrm{I}$ & II. 8 & IIII \\
\hline 18:2 & 53.2 & $50 \cdot 2$ & $51 \cdot 4$ & 15.9 & 16.8 & 12.0 & 13.4 \\
\hline $18: 3$ & $6 \cdot 3$ & $9 \cdot 4$ & 8.7 & $1 \cdot 6$ & $I \cdot 6$ & $I \cdot I$ & 0.6 \\
\hline
\end{tabular}

Balance experiments. The pigs were housed in cages equipped for the separate collection of faeces and urine. The animals were fed twice daily at the rate of $\mathrm{I} \cdot \mathrm{okg} /$ day, for a preliminary period of 4 days before the collection of faeces began. A collection period of to days followed, during which daily intakes of food and output of faeces were recorded. Daily collections of faeces were stored at $\mathrm{I}-3^{\circ}$, then bulked and homogenized at the end of the collection period. At the end of the first collection period, the daily food intake was increased to $\mathrm{I} \cdot \mathbf{2} \mathrm{kg}$, and a 4 -day preliminary period was allowed before beginning the second ro-day collection period. On the day following the end of this collection period, diets containing interesterified fats were replaced at one meal $(600 \mathrm{~g}$; about $200 \mu \mathrm{c}$ ) only by their labelled counterparts, prepared as described above. A small sample of the meal was retained for analysis, and the amount consumed by the animal recorded. Daily collections of faeces were analysed for radioactivity until no further activity could be detected (usually 5 days). Faeces were then bulked and homogenized.

Analytical methods. Representative samples of food and faeces were analysed according to the scheme outlined in Fig. I. Faecal samples (about Io g) were homogenized with concentrated hydrochloric acid ( $\mathrm{r} \mathrm{ml}$ ) and a minimal quantity of water and allowed to stand. Sufficient anhydrous calcium sulphate was then added to give a friable mixture. The mixture was transferred quantitatively to a Soxhlet thimble and 
extracted for $8 \mathrm{~h}$ with light petroleum (b.p. $40-60^{\circ}$ ) ( $50 \mathrm{ml}$ ). A similar amount of wet faeces was taken for the determination of dry weight.

Feedstuffs were extracted with light petroleum (b.p. $40-60^{\circ}$ ) for 8 h. After evaporation of the solvent the extracted lipid was weighed; with radioactive samples a subsample (about I00 mg) of known weight was assayed by liquid scintillation counting (Packard Tri-Carb Liquid Scintillation Spectrometer) in solution in $0.4 \% 2,5-$ diphenyloxazole in toluene ( $5 \mathrm{ml}$ ). An external standard of ${ }^{226} \mathrm{Ra}$ was used to correct for quenching.

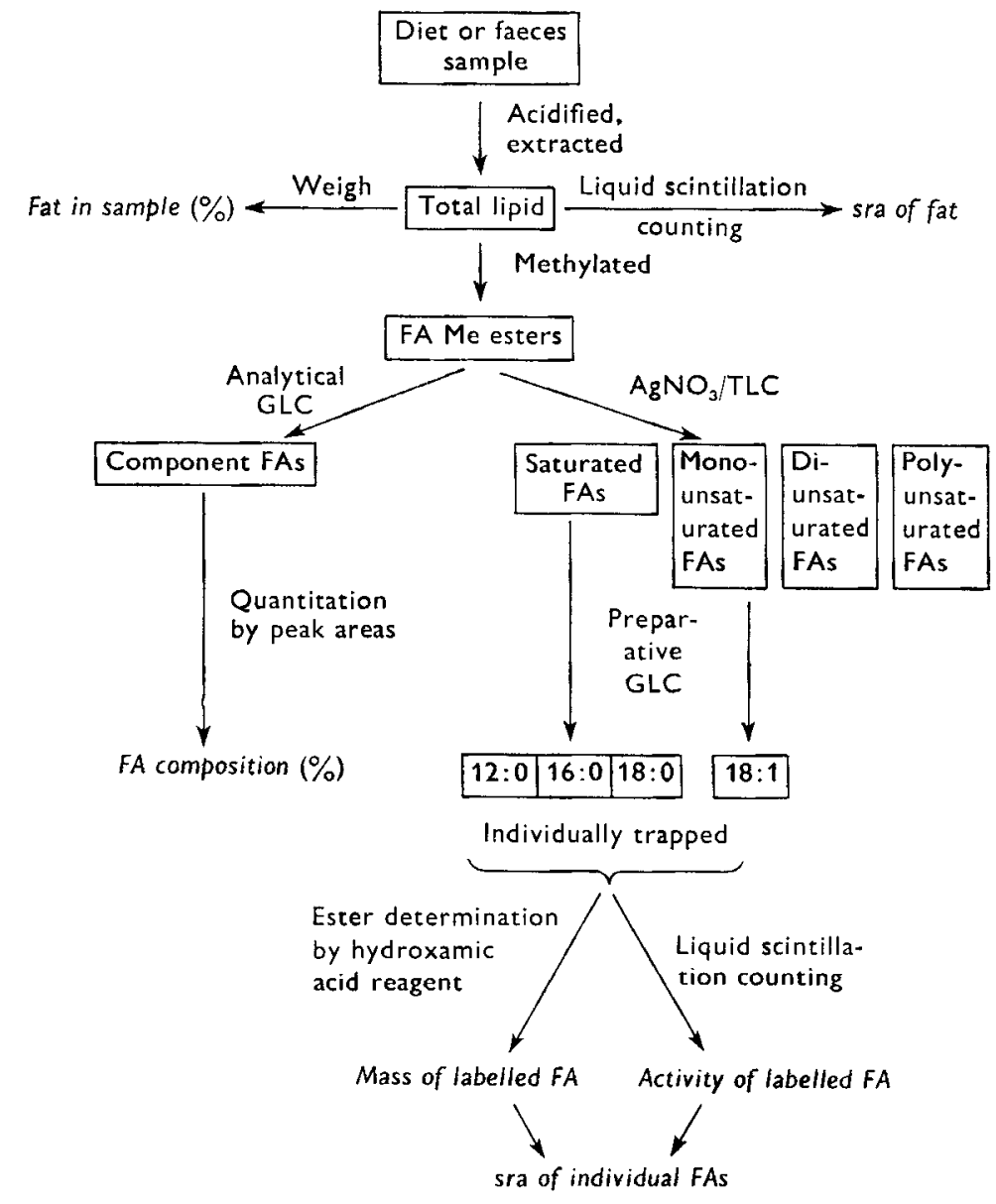

Fig. I. Scheme for analysis of food and faeces. sra, specific radioactivity; FA, fatty acid; Me, methyl; GLC, gas-liquid chromatography; TLC, thin-layer chromatography.

Extracted dietary or faecal fat (about $50 \mathrm{mg}$ ) was methylated by refluxing in methanol-benzene- $\mathrm{H}_{2} \mathrm{SO}_{4}(20: 10: \mathrm{I}, \mathrm{v} / \mathrm{v})$ for $90 \mathrm{~min}$, and the methyl esters were separated by gas-liquid chromatography (GLC) on a $180 \times 0.4 \mathrm{~cm}$ column of polyethylene glycol succinate stationary phase (10\%) supported on Anakrom (Analabs Inc, Hamden, Conn., USA) at $180^{\circ}$.

Determination of the specific radioactivity of individual fatty acids in the diets and 
in faeces was carried out by first separating their methyl esters (about $10 \mathrm{mg}$ ) into groups according to degree of unsaturation on chromatoplates of silica gel impregnated with silver nitrate (Morris, 1962) employing double-development in a diethyl etherhexane $(5: 95, \mathrm{v} / \mathrm{v})$ system. The saturated methyl ester band (containing labelled $\mathrm{C}_{12: 0}, \mathrm{C}_{16: 0}$ and $\mathrm{C}_{\text {18:0}}$ ) and the monounsaturated band (containing labelled $\mathrm{C}_{18: 1}$ ) were scraped off, and the methyl esters eluted in diethyl ether. Each group of methyl esters was then separated by preparative GLC on a $120 \times 0.6 \mathrm{~cm}$ column of polyethylene glycol succinate ( $15 \%$ ) on Chromosorb W (Johns-Manville Company Ltd, London, $\mathrm{SE}_{\mathrm{I}}$ ). The separated methyl esters were trapped in tubes packed with Anakrom (6o-80 mesh) and held at $-60^{\circ}$ in a solid $\mathrm{CO}_{2}$-isopropyl alcohol mixture. They were eluted from the tubes in light petroleum (b.p. $\left.40-60^{\circ}\right)(20 \mathrm{ml})$ and a portion of the resulting solution was taken for the determination of the esterified fatty acid content by the hydroxamic acid ester method of Morgan \& Kingsbury (1959). A further portion was taken for counting by liquid scintillation.

In the experiments to assess the extent of hydrogenation of oleic acid in the digestive tract, faecal lipids, after methylation, were first fractionated by thin-layer chromatography on silica gel with a solvent system of diethyl ether-hexane $(30: 70, \mathrm{v} / \mathrm{v})$ to separate the hydroxy methyl esters of fatty acids from the methyl esters. The 9- and ro-hydroxy methyl isomers were not resolved in this system, and were analysed as a single group. The methyl ester fraction was then eluted and rechromatographed on thin-layer plates of silica gel impregnated with silver nitrate.

From the amount of fat ingested with the labelled meal and its specific radioactivity, the intake of radioactivity was calculated, and the total output of radioactivity was determined from the quantity and specific radioactivity of the faecal fat. The intake and output of radioactivity associated with each fatty acid was calculated in the same manner. The true digestibility of a fat or fatty acid is then given by the relationship:

$$
\text { true digestibility }=\frac{\text { ingested labelled fat or FA }- \text { excreted labelled fat or FA }}{\text { ingested labelled fat or FA }} \times 100 .
$$

\section{RESULTS}

All pigs grew well throughout the trial and gained weight at a rate of about $450 \mathrm{~g} /$ day during the balance periods.

Digestibilities of fat. Mean values for the apparent and corrected digestibilities of the natural and interesterified fats are presented in Table 3 , together with the true digestibilities of the interesterified fats calculated from the proportion of radioactivity retained. Apparent digestibilities were corrected on a within-block basis; i.e. in those blocks which included a control treatment, the endogenous faecal fat output of the control animal was used to correct the apparent digestibilities for pigs in that block only. The corrected digestibilities of both interesterified soya-bean oil and coconut oil were almost identical with their true digestibilities; the corresponding values for lard were slightly more divergent. All the fats were well digested, but both soya-bean oil and coconut oil had a significantly higher digestibility coefficient than lard. 
There was no significant difference between the digestibility of any natural fat and its interesterified counterpart.

Digestibilities of fatty acids. The digestibilities of the major component fatty acids of each fat are shown in Table 4. In general, there was a much greater variability in the digestibilities of individual fatty acids than in those of the fats. The deviations were most marked with stearic acid and to a lesser extent with palmitic acid, and were most apparent when the intake of the acid was low, as when soya-bean oil or coconut oil was fed.

Table 3. Digestibility coefficients for natural and interesterified soya-bean oil, lard and coconut oil

\begin{tabular}{|c|c|c|c|c|}
\hline \multicolumn{5}{|c|}{ lard and coconut oul } \\
\hline \multirow[b]{2}{*}{ Soya-bean oil } & & Apparent & Cotrected & True \\
\hline & $\begin{array}{l}\text { Natural } \\
\text { Interesterified }\end{array}$ & $\begin{array}{l}79 \cdot 4 \\
8 \mathrm{r} \cdot 5\end{array}$ & $\begin{array}{l}89 \cdot 9 \\
93 \cdot 1\end{array}$ & - \\
\hline Lard & $\begin{array}{l}\text { Natural } \\
\text { Interesterified }\end{array}$ & $\begin{array}{l}73 \cdot 8 \\
68 \cdot 1\end{array}$ & $\begin{array}{l}84 \cdot 9 \\
82 \cdot 6\end{array}$ & $\overline{85 \cdot 2}$ \\
\hline Coconut oil & $\begin{array}{l}\text { Natural } \\
\text { Interesterified }\end{array}$ & $\begin{array}{l}77 \cdot 5 \\
83 \cdot 6\end{array}$ & $\begin{array}{l}9 x \cdot 4 \\
92 \cdot 4\end{array}$ & $\overline{92 \cdot 8}$ \\
\hline \multicolumn{2}{|c|}{ Coefficient of variation (\%) } & $\begin{array}{l}8 \\
10 \cdot 0 \\
7 \cdot 4\end{array}$ & $\begin{array}{l}4 \\
5 \cdot 2 \\
7 \cdot 0\end{array}$ & 2 \\
\hline
\end{tabular}

\section{Table 4. Digestibility coefficients (\%) for individual fatty acids* in} the fat-supplemented diets $\uparrow$

\begin{tabular}{|c|c|c|c|c|c|c|c|c|c|}
\hline \multirow{2}{*}{$\begin{array}{l}\text { Fatty } \\
\text { acid }\end{array}$} & \multirow{2}{*}{$\begin{array}{c}\text { Soya-bean } \\
\text { oil } \\
\text { (corrected) }\end{array}$} & \multicolumn{2}{|c|}{$\begin{array}{l}\text { Interesterified } \\
\text { soya-bean oil }\end{array}$} & \multirow{2}{*}{$\begin{array}{c}\text { Lard } \\
\text { (corrected) }\end{array}$} & \multicolumn{2}{|c|}{$\begin{array}{l}\text { Interesterified } \\
\text { lard }\end{array}$} & \multirow{2}{*}{$\begin{array}{c}\text { Coconut } \\
\text { oil } \\
\text { (corrected) }\end{array}$} & \multicolumn{2}{|c|}{$\begin{array}{l}\text { Interesterified } \\
\text { coconut oil }\end{array}$} \\
\hline & & Corrected & True & & Corrected & True & & Corrected & True \\
\hline $12: 0$ & - & - & - & - & - & - & $86 \cdot 8$ & $9 \mathrm{I}_{4} 4$ & $95 \cdot 2$ \\
\hline I $4: 0$ & - & - & - & $95 \cdot 8$ & $86 \cdot 6$ & - & $79 \cdot 0$ & $78 \cdot 9$ & - \\
\hline I6:0 & $86 \cdot I$ & $95 \cdot 2$ & $92 \cdot 9$ & $79^{\circ} \circ$ & $7 x \cdot 8$ & 63.4 & $84 \cdot 6$ & $78 \cdot I$ & $91 \cdot 0$ \\
\hline I8:0 & $I$ & 40.0 & $89 \cdot 9$ & $46 \cdot 7$ & $52 \cdot 6$ & $46 \cdot 0$ & 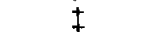 & \pm & $69 \cdot 2$ \\
\hline 18: I & $93 \cdot 6$ & 95.5 & $9 \mathbf{I} \cdot 8$ & 96.6 & $97 \cdot 6$ & 96.0 & 100.0 & $\ddagger$ & $95 \cdot 3$ \\
\hline $18: 2$ & $98 \cdot 8$ & 99.5 & - & 100.0 & 100.0 & - & $\ddagger$ & $\ddagger$ & - \\
\hline $18: 3$ & 100.0 & $97^{\circ}$ & - & - & - & - & - & - & - \\
\hline
\end{tabular}

Comparison of the corrected and true digestibilities for individual fatty acids showed greater differences than with the fats (Table 3). The true digestibility of any individual fatty acid is only valid, however, if there is no significant interconversion of the acid in the alimentary tract, or in the tissues if absorbed fatty acids are returned to the tract in intestinal secretions. Interconversion of either lauric or palmitic acid, or the further conversion of stearic acid is improbable, but there is evidence in man that hydrogenation of oleic acid to stearic acid occurs in the digestive tract (Wollaegar, Lundberg, Chipault \& Mason, I953; Bergström \& Blomstrand, 1956). In separate 
experiments in which $\left[\mathrm{r}^{14} \mathrm{C}\right]$ oleic acid was given to the experimental animals, examination of the faecal lipid 2 days after the ingestion of the labelled meal showed that, of the total activity recovered in the faeces, about $30 \%$ was associated with stearic acid. After 4 days, though the level of radioactivity in faeces was much lower, the percentage

Table 5. Endogenous fat production of pigs receiving diets containing labelled fats

\begin{tabular}{|c|c|c|c|c|c|}
\hline Fat & Pig no. & $\begin{array}{l}\text { Specific } \\
\text { radio- } \\
\text { activity } \\
(\mu \mathrm{c} / \mathrm{g})^{*}\end{array}$ & $\begin{array}{c}\text { Total } \\
\text { faecal fat } \\
\text { production } \\
\text { (g/day) }\end{array}$ & $\begin{array}{c}\text { Faecal fat } \\
\text { of dietary } \\
\text { origin } \\
\text { (g/day) }\end{array}$ & $\begin{array}{c}\text { Endogenous } \\
\text { fat } \\
\text { production } \\
\text { (g/day) }\end{array}$ \\
\hline Interesterified soya-bean oil & $\begin{array}{r}686 \\
195\end{array}$ & $\begin{array}{l}1 \cdot 90 \\
1.88\end{array}$ & $\begin{array}{l}22 \cdot 0 \\
18 \cdot 1\end{array}$ & $\begin{array}{r}11.6 \\
9.6\end{array}$ & $\begin{array}{r}10.4 \\
8.5\end{array}$ \\
\hline Interesterified lard & $\begin{array}{l}419 \\
359\end{array}$ & $\begin{array}{l}3.30 \\
2.40\end{array}$ & $\begin{array}{l}47 \cdot 2 \\
55 \cdot 3\end{array}$ & $\begin{array}{l}14.3 \\
23.0\end{array}$ & $\begin{array}{l}32 \cdot 9 \\
32 \cdot 3\end{array}$ \\
\hline Interesterified coconut oil & $\begin{array}{l}089 \\
418\end{array}$ & $\begin{array}{l}2.06 \\
\mathrm{I} .58\end{array}$ & $\begin{array}{r}22 \cdot 6 \\
13 \cdot 7\end{array}$ & $\begin{array}{r}11 \cdot 0 \\
8.7\end{array}$ & $\begin{array}{r}11 \cdot 6 \\
5 \cdot 0\end{array}$ \\
\hline
\end{tabular}

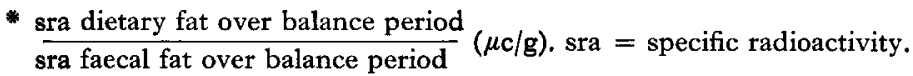

Table 6. Endogenous fatty acid production (g/day) of pigs receiving labelled diets

\begin{tabular}{|c|c|c|c|c|c|c|}
\hline \multirow[b]{2}{*}{ Fatty acid } & \multicolumn{2}{|c|}{$\begin{array}{l}\text { Interesterified } \\
\text { soya-bean oil }\end{array}$} & \multicolumn{2}{|c|}{$\begin{array}{c}\text { Interesterified } \\
\text { lard }\end{array}$} & \multicolumn{2}{|c|}{$\begin{array}{l}\text { Interesterified } \\
\text { coconut oil }\end{array}$} \\
\hline & Pig 686 & Pig I95 & Pig 419 & Pig 359 & Pig 41 8 & Pig ${ }_{3} 6_{3}$ \\
\hline I2:0 & - & - & - & - & - & $I \cdot O$ \\
\hline $16: 0$ & $2 \cdot 7$ & $I \cdot 9$ & 8.9 & $8 \cdot 0$ & $\mathbf{I} \cdot \mathbf{I}$ & $2 \cdot 2$ \\
\hline I 8:0 & $3 \cdot 5$ & $4 \cdot I$ & 10.0 & $12 \cdot 1$ & $I \cdot 9$ & 2.6 \\
\hline I 8: I & $2 \cdot 0$ & 3.0 & 6.2 & $2 \cdot 6$ & 0.8 & 0.7 \\
\hline
\end{tabular}

distribution between the various acids was as follows: oleic acid, $45 \%$; stearic acid, $45 \%$; and 9- or ro-hydroxy stearic acid, 10\%. On the assumption that oleic acid is about $95 \%$ digestible, this represents a conversion of about $2-3 \%$ dietary oleic acid into faecal stearic acid. Undoubtedly, the extent of this conversion varies from pig to pig, depending upon age, environmental history and other factors, and it was not feasible to apply a correction factor to the endogenous outputs of stearic and oleic acids. It is a factor which should be borne in mind, however, when considering the apparent, corrected or true coefficients of digestibility of these acids.

Endogenous fat production. The mean specific radioactivity of dietary fat over the balance period was calculated from the specific radioactivity of the fat administered in the single labelled meal and the amount of unlabelled diet consumed over the remainder of the period. The specific radioactivity of faecal fat over the same period was measured for the determination of true digestibility. On the assumption that digestibility remained constant over the balance period, the ratio of the two values was a direct measure of the dilution of exogenous fat by endogenous fat. From this ratio, the 
contribution to total fat production of fat of dietary and of endogenous origin was calculated. Alternatively, the values were derived by using the true digestibility value determined for the balance period and the recorded fat intake to give the output of faecal fat of immediate dietary origin. Endogenous fat production was the difference between total fat production and this value. The results presented in Table 5 indicate a much greater production of endogenous fat with the lard-supplemented diet than with the diet supplemented with either coconut or soya-bean oil. The measured 'endogenous' outputs of pigs on the control diet were $\mathrm{I} \cdot \mathrm{I} \mathrm{g} /$ day (period $\mathrm{I}$ ) and $14.7 \mathrm{~g} /$ day (period 2); these figures are the mean of four values.

Similar calculations were made for individual fatty acids (Table 6). A greater endogenous production of fatty acids was expected on the lard-supplemented diet, since endogenous fat production on this diet was greater than on diets based on the other two fats. However, the level of endogenous palmitic acid produced was disproportionately higher when lard was given. The values for stearic and oleic acids were undoubtedly affected by the hydrogenation shown to occur in the digestive tract.

\section{DISCUSSION}

In determining the true digestibility of a fat by the labelled fatty acid technique, ideally each component fatty acid of the fat should be labelled. With most fats this is clearly impracticable. The fat digestibility values obtained in the present work are the mean digestibilities of the fatty acids that were labelled. With lard and coconut oil the major proportion of the fatty acids was labelled, but with soya-bean oil only about $40 \%$ were labelled.

The close agreement between the corrected and true digestibilities of each fat examined suggests that the conventional correction for endogenous fat production provides a meaningful estimate of the true digestibility of a fat, under the conditions of these experiments. However, the assumption on which this correction is based, namely that endogenous fat production is independent of both the level and nature of dietary fat, appears not to be strictly correct. Although the number of animals given the labelled diets was necessarily limited, the calculated values for endogenous fat indicated that endogenous fat production was altered when the type of dietary fat was changed. The effects of the discrepancies between measured and calculated endogenous faecal fat levels on the comparison between the corrected and true digestibilities for animals on different fat diets were largely masked by the errors in faecal collection and analysis, and by the between-animal variability inherent in trials of this nature.

The conventional correction for endogenous lipid excretion and the comparison with true digestibility was less satisfactory when applied to individual fatty acids, particularly when endogenous output was high relative to exogenous output.

In the present work no results on the effect of the level of dietary fat on endogenous fat production were obtained. The present results suggested that both the amount and composition of endogenous fat were influenced by the nature of dietary fat. The results provide no information on the sources of endogenous faecal fat, or its possible 
relationship to dietary fat. Holasek (1954) and Bergström \& Blomstrand (1956) contend that intestinal micro-organisms are the main source of endogenous faecal fatty acids in the rat and man, though Bergström \& Blomstrand (1956) did not exclude some contribution from intestinal secretions or desquamated epithelial cells of the small intestine. In this respect it may be significant that in the present work the highest level of endogenous fat and fatty acid production was recorded when the digestibilities were lowest, i.e. dietary lard and palmitic acid in the lard-supplemented ration. This may suggest a greater contribution to faecal fat production of lipid from desquamated mucosal cells than has previously been recognized. There is some evidence that the lipid of mucosal cells shed in the small intestine is rich in the more poorly assimilated fatty acids (Freeman, Noakes, Annison \& Hill, r968). The classification of lipid from this source as truly endogenous depends upon the interpretation placed on this term; it may perhaps be more rigorously termed 'not of immediate dietary origin'.

The occurrence of hydrogenation of oleic acid in the pig is similar to that reported in man (Wollaegar et al. 1953; Bergström \& Blomstrand, 1956). The labelling in 9- or Io-hydroxy stearic acid when [ $\left.{ }^{-1}{ }^{11} \mathrm{C}\right]$ oleic acid was administered suggests that hydration of oleic acid also occurs in the digestive tract of the pig. Conversion of oleic acid into Io-hydroxy stearic acid by a pseudomonad has been reported (Waller, Benedict \& Jackson, 1962) and James, Webb \& Kellock (1961) found ro-hydroxy stearic acid, as well as smaller amounts of the 6-, 7-, 8- and 9-isomers in the faeces of human beings with steatorrhoea.

It was clear that the digestibilities of individual fatty acids were influenced both by their level of inclusion in the fat, and by the other component fatty acids. Stearic acid, generally considered to be a poorly digested fatty acid, provides a good example. When present in small concentrations in dietary fat and in the presence of large proportions of dietary unsaturated fatty acids, as in soya-bean oil, its digestibility was high $(90 \%)$. At a similarly low level of inclusion, but in the presence mainly of mediumchain fatty acids (i.e. in coconut oil) its digestibility was also high $(70 \%)$ when compared with its value in lard $(46 \%)$. The low digestibility of stearic acid in lard results in the poorer digestibility coefficient of this fat relative to coconut oil and soya-bean oil.

No evidence was found that the glyceride structure of any of the fats examined had a significant effect on the digestibility of the fat. In common with our previous experience of natural fats examined in pigs maintained under the conditions used for balance experiments, each of the fats used in the present studies was well digested. The positional distribution of fatty acids on the triglyceride moiety may well assume importance if an unusually high level of long-chain saturated fatty acid limits over-all digestibility. The results suggest, however, that fatty acid composition, rather than glyceride structure, normally exerts the greater influence on fat digestibility. 


\section{REFEREN CES}

Bayley, H. S. \& Lewis, D. (1965). F. agric. Sci., Camb. 64, 367.

Bergström, S. \& Blomstrand, B. (1956). In Biochemical Problems of the Lipids, p. 323. [G. Popjak and E. Le Breton, editors.] London: Butterworths.

Freeman, C. P., Noakes, D. E., Annison, E. F. \& Hill, K. J. (1968). Br. F. Nutr. 22, 739.

Holasek, A. (1954). Hoppe-Seyler's Z. physiol. Chem. 298, 55.

James, A. T., Webb, J.P. W. \& Kellock, T. D. (1961). Biochem. F. 78, 333.

Morgan, D. M. \& Kingsbury, K. J. (1959). Analyst, Lond. 84, 409.

Morris, L. J. (1962). Chemy Ind. p. $123^{8 .}$

Täufel, K., Franzke, C. \& Achtzehn, M. (1958). Fette Seifen AnstrMittel. 6o, 456.

Waller, L. L., Benedict, R. G. \& Jackson, R. W. (1962). Archs Biochem. Biophys. 99, 249.

Wollaegar, E. E., Lundberg, W. O., Chipault, J. R. \& Mason, H. L. (1953). Gastroenterology $24,422$. 